\title{
Hubungan Tingkat Ekspresi p15 terhadap Nevus Melanositik dan Melanoma Maligna
}

\author{
Renny Apliza Nasution ${ }^{1}$, Ika Kartika ${ }^{1}$, Zulkarnain Musa ${ }^{1}$, Theodorus ${ }^{2}$ \\ ${ }^{1}$ Departemen Patologi Anatomi, Fakultas Kedokteran, Universitas Sriwijaya, Palembang \\ ${ }^{2}$ Unit Statistik dan Epidemiologi, Fakultas Kedokteran, Universitas Sriwijaya, \\ Palembang \\ Email: rennydarmawan@yahoocom \\ Received 22 Sep 2020; accepted 25 Mei 2021
}

\begin{abstract}
Abstrak
Latar Belakang. Lesi melanositik memiliki gambaran morfologi dan sitomorfologi yang luas mencakup lesi jinak yaitu nevus melanositik dan lesi ganas yaitu melanoma maligna. Beberapa gambaran nevus melanositik menyerupai melanoma. p15 merupakan gen penekan tumor dan biomarker yang kuat sehingga dapat digunakan untuk membedakan antara nevus dan melanoma. Tujuan. Mengetahui hubungan tingkat ekspresi p15 pada nevus dan melanoma. Metodologi. Penelitian ini merupakan penelitian deskriptif observasional dengan desain serial kasus sejak 1 Januari 2015 sampai 30 Desember 2019. Sebanyak 60 sampel dilakukan pemeriksaan imunohistokimia menggunakan antibodi p15. Ekspresi p15 dinilai berdasarkan proporsi sel tumor yang terpulas dan intensitas pulasan. Analisis statistik menggunakan SPSS versi 23.0. Hasil. Nevus melanositik paling banyak dijumpai pada perempuan (76,7\%), pada kelompok usia <55 tahun (90\%), lokasi tumor pada kepala dan leher $(83,3)$ dan pada tipe histopatologi dermal naevus $(53,3 \%)$. Melanoma maligna paling banyak ditemukan pada jenis kelamin laki-laki (53,6\%), pada kelompok usia $<55$ tahun $(57,1 \%)$, lokasi tumor pada kepala dan leher $(35,7 \%)$ dan pada tipe histopatologi nodular melanoma $(42,9 \%)$. Terdapat hubungan bermakna antara tingkat ekspresi p15 dengan lesi melanositik (nevus melanositik dan melanoma maligna) ( $r=0,9666 ; \mathrm{p}=0,000)$. Kesimpulan. Ekspresi p15 tinggi dijumpai pada nevus melanositik dan rendah pada melanoma maligna. Terdapat hubungan bermakna antara tingkat ekspresi p15 dengan lesi melanositik (nevus melanositik dan melanoma maligna). Semakin rendah ekspresi p15 maka semakin besar kemungkinan terjadi melanoma maligna.
\end{abstract}

Kata kunci: Ekspresi p15, nevus melanositik, melanoma maligna

\begin{abstract}
The correlation of expression p15 with melanocytic naevus and malignant melanoma. Background. Melanocytic lesions have a broad morphological and cytomorphological picture including benign conditions or melanocytic naevus and malignant melanoma. Some features of a melanocytic nevus mimicking melanoma. p15 is a tumor suppressor gene and is a robust biomarker that can be used to differentiate between nevus and melanoma. This study aims to determine the correlation between p15 expression in melanocytic naevus and malignant melanoma. Methods. This research is an observational descriptive study with a case series design, conducted from January 1st, 2015 to December 30th 2019. A total of 60 samples were subjected to immunohistochemical examinations using antibody p15. The expression p15 is based on tumor cell proportion and intensity. Statistical analysis using SPSS version 23. Result. Melanocytic nevus was predominantly female (76.7\%), age group <55 years (90\%), location of tumors on the head and neck (83.3), histopathological type of dermal naevus (53.3\%). Malignant melanoma was mostly found in men (15, 53.6\%), age group $<55$ years $(57.1 \%)$, the location of tumors on the head and neck (35.7\%), type histopathology of nodular melanoma (42.9\%). The correlation between p15 level expression and melanocytic lesions (melanocytic nevus and malignant melanoma $)(r=0.9666 ; p=0.000)$. Conclusion. High expression of $p 15$ was found in melanocytic nevus and low in malignant melanoma. There was correlation between p15 level expression and melanocytic lesions (melanocytic nevus and malignant melanoma). The lower the p15 expression, the more likely malignant melanoma will occur.
\end{abstract}

Keywords: p15 expression, melancytic naevus, malignant melanoma 


\section{Pendahuluan}

Melanoma maligna umumnya berasal dari nevus melanositik akibat berbagai faktor risiko. Berdasarkan data GLOBOCAN 2018, diperkirakan terdapat 300.000 kasus baru melanoma maligna pertahun yang mengakibatkan 60.000 kematian $^{1}$ dan di Indonesia terdapat sebanyak 1392 kasus melanoma maligna. Syahputri dkk menyatakan ada 30 kasus melanoma maligna di RSMH pada tahun 2009-2013. ${ }^{2}$ Berdasarkan World Health Organisation (WHO), acral lentiginous melanoma merupakan subtipe yang paling banyak pada populasi Afrika dan Asia serta memiliki prognosis paling buruk. ${ }^{1,3}$

Prognosis melanoma sangat jelek sehingga diagnosis dini sangat diperlukan. Menegakkan diagnosis yang akurat untuk lesi melanositik selalu menjadi tantangan bagi ahli patologi karena adanya kemiripan gambaran histopatologi. Sebagai contoh, melanoma sering salah didiagnosis sebagai dysplastic naevus dan spitz naevus. Nevus melanositik memiliki gambaran mikroskopik bervariasi dan tumpang tindih dengan melanoma maligna sehingga keduanya harus dibedakan. Beberapa nevus melanositik lainnya yang memiliki gambaran menyerupai melanoma maligna seperti compound nevus, pigmented spindle cell nevus (reed nevus), cellular blue nevus, deep penetrating nevus, acral nevus dan recurrent nevus. Pada reed nevus dijumpai selsel melanosit berbentuk spindel, uniformis dengan beberapa sel atipik, inti hiperkromatik dan anak inti menonjol, gambaran mitosis abnormal juga dapat dijumpai. ${ }^{4}$ Hale dkk menyatakan nevoid melanoma memiliki kemiripan dengan nevus melanositik karena struktuk dome-shaped atau verrucous, simetris dan sel-sel yang tampak maturasi pada dermis. ${ }^{5}$ Theodosiou dkk menyatakan naevoid melanoma menyerupai compound dan dermal nevus. ${ }^{6}$ Costa dkk meneliti adanya kemiripan antara melanomas associated with blue nevus dengan celluler blue nevus. ${ }^{7}$ Kesalahan diagnosis antara melanoma dan nevus melanositik memiliki implikasi medikolegal. Stephen dkk menyatakan kesalahan diagnosis melanoma terjadi pada $13 \%$ dari total malpraktik medis terkait patologi dan merupakan kelompok klaim malpraktek terbesar kedua. ${ }^{8,9}$

Melanoma maligna dipengaruhi oleh faktor genetik, ras, tipe kulit dan gender. Faktor tambahan lainnya yang mempengaruhi adalah usia, jumlah, ukuran dan tipe nevus pigmentosus. Faktor lingkungan juga mempengaruhi, terutama akumulasi dari lamanya pajanan terhadap sinar matahari. Faktor genetik yang berperan salah satunya adalah mutasi genetik yang mengenai kromosom 9p21 dengan lokus p16 dan p15 yang berfungsi untuk mengatur siklus sel agar tetap normal. Mutasi pada lokus p16 dan p15 akan menyebabkan perubahan siklus sel yang agresif sehingga dapat terbentuklah melanoma maligna. ${ }^{10,11}$ Penelitian ini akan menilai hubungan tingkat ekspresi p15 terhadap nevus melanositik dan melanoma maligna di RSUP Dr.Mohammad Hoesin Palembang.

\section{Metode Penelitian}

Penelitian ini adalah deskriptif observasional dengan desain serial kasus yang dilakukan di Sentra Diagnostik Patologi Anatomi Fakultas Kedokteran Universitas Sriwijaya/RSUP Dr. Mohammad Hoesin Palembang mulai bulan 1 Januari sampai Mei 2020. Populasi penelitian ini berupa seluruh arsip preparat pasien yang telah di diagnosis secara histopatologi sebagai nevus melanositik dan melanoma maligna di Sentra Diagnostik Patologi Anatomi Fakultas Kedokteran Universitas Sriwijaya/ RSUP Dr. Mohammad Hoesin Palembang periode 1 Januari 2015 sampai 30 Desember 2019. Kriteria inklusi pada penelitian ini adalah Arsip preparat Hematoksilin-Eosin yang didiagnosis sebagai nevus melanositik dan melanoma maligna, blok parafin dari preparat tersebut di atas dalam keadaan baik dan mengandung massa tumor dengan jumlah cukup (minimal 100 sel tumor) untuk dilakukan pulasan imunohistokimia dan data rekam medik yang dibutuhkan lengkap. Sedangkan kriteria eksklusi adalah kasus dengan diagnosis histopatologi belum pasti 
atau masih ada diagnosis banding dan mengandung massa tumor yang tidak cukup untuk dijadikan sampel penelitian. Sampel penelitian diambil dengan menggunakan tehnik proportional random sampling sesuai dengan proporsi tipe histopatologi nevus melanositik dan melanoma maligna. Variabel bebas pada penelitian ini adalah ekspresi p15 dan variable terikat adalah usia, jenis kelamin, lokasi tumor, dan tipe histopatologi nevus melanositik dan melanoma maligna.

Ekspresi p15 adalah hasil ekspresi protein p15 dimana sel-sel melanosit pada nevus melanositik maupun sel-sel melanoma maligna terlihat immunoreaktif pada inti sel dan sitoplasma ditandai dengan warna coklat dengan intensitas pewarnaan lemah sampai kuat. Ekspresi ini diukur melalui pemeriksaan imunohistokimia dengan antibodi p15. Penilaian ekspresi p15 pada penelitian ini secara semikuantitatif yaitu menilai proporsi sel tumor (P) dan intensitas (I) yang terpulas. Proporsi sel tumor dibagi menjadi empat kelompok yaitu 0 : terwarnai $<5 \%$; 1 : terwarnai $5-25 \%$; 2: terwarnai $26 \%-50 \%$; dan 3: terwarnai $>50 \%$. Intensitas ekspresi p15 ditentukan dengan cara mencari ekspresi p15 yang dominan dari 5 lapang pandang besar yang telah dihitung proporsi sel tumornya, dibagi menjadi tiga kelompok yaitu 0: tidak terwarnai sampai terwarnai lemah atau coklat muda pada inti dan sitoplasma; 1: terwarnai lemah/coklat muda sampai sedang/coklat terang pada inti dan sitoplasama; dan 2: terwarnai sedang/coklat terang sampai kuat/coklat gelap pada inti dan sitoplasma (Gambar 1). Penilaian skor ekspresi p15 pada penelitian ini berdasarkan perkalian proporsi sel tumor yang terpulas (P) dan intensitas (I) pulasan dimana didapatkan skor 0 sampai 6 , kemudian dibagi menjadi dua kelompok, yaitu ekspresi rendah: skor 0-2 dan ekspresi tinggi: skor $>2 .^{12}$

Variabel subtipe histopatologi nevus melanositik berdasarkan gambaran histopatologis sesuai dengan klasifikasi WHO tahun 2017 dengan pewarnaan rutin HE. Subtipe histopatologi nevus melanositik terbagi kedalam Compund nevus, Dermal nevus, dan Spitz nevus. Variabel subtipe histopatologi melanoma maligna berdasarkan gambaran histopatologis sesuai dengan klasifikasi WHO tahun 2017 dengan pewarnaan rutin HE. Subtipe histopatologi melanoma maligna terbagi ke dalam mucosal melanoma, nodular melanoma, acral melanoma dan conjunctival melanoma. Seluruh data dicatat dalam status penelitian selanjutnya dilakukan entry cleaning, editing dan coding ke computer dan dianalisis menggunakan program Statistical Programme for Social Sciences (SPSS) versi 23.

\section{Hasil}

Didapatkan sampel penelitian sebanyak 60 spesimen dari hasil operasi biopsi eksisi yang telah di diagnosis secara histopatologi. Terdapat dua sampel yang di eksklusi yaitu sampel kasus nomor 44 dan 53 dengan diagnosa histopatologi conjunctival melanoma dan nodular melanoma karena setelah dilakukan pembacaan imunohistokimia kedua sampel ini tidak dapat dibedakan antara ekspresi p15 dengan pigmen melanin yang cukup banyak sehingga tidak dapat dilakukan analisa. Dari 58 sampel didapatkan sebanyak masing-masing $30 \quad(51,7 \%)$ sampel nevus melanositik yang terdiri dari compound naevus $12(40 \%)$, dermal naevus $16(53,3 \%)$, spitz naevus $2(6,7 \%)$ dan $28(48,3 \%)$ sampel yang didiagnosis melanoma maligna yang terdiri dari beberapa tipe histopatologi yaitu 9 $(32,1 \%)$ mucosal melanoma, $12 \quad(42,9 \%)$ nodular melanoma, $6(21,4 \%)$ acral melanoma $1(3,6 \%)$ conjunctival melanoma berdasarkan tehnik pengambilan sampel dengan metode proportional random sampling (Tabel 1.1). 


\begin{tabular}{lcc} 
Tabel 1.1 Karakteristik klinikopatologi berdasarkan tipe histopatologi \\
\hline Karakteristik & \multicolumn{2}{c}{ Jenis Lesi } \\
\cline { 2 - 3 } & Nevus melanositik (n-30) & Melanoma maligna (n=28) \\
\hline Tipe Histopatologi & $12(40,0)$ & $0(0,0)$ \\
Compound naevus & $16(53,3)$ & $0(0,0)$ \\
Dermal naevus & $2(6,7)$ & $0(0,0)$ \\
Spitz naevus & $0(0,0)$ & $9(32,1)$ \\
Mucosal melanoma & $0(0,0)$ & $12(42,9)$ \\
Nodular melanoma & $0(0,0)$ & $6(21,4)$ \\
Akral melanoma & $0(0,0)$ & $1(3,6 \%)$ \\
Conjunctival & & \\
melanoma & & \\
\hline
\end{tabular}

Dari 58 sampel didapatkan sebanyak 30 pasien $(51,7 \%)$ didiagnosis nevus melanositik dan 28 sampel $(48,3 \%)$ didiagnosis melanoma maligna. Berdasarkan jenis lesi tersebut didapatkan hasil dari 30 sampel nevus melanositik sebanyak $27(90 \%)$ berusia $<55$ tahun, sebanyak $3(10 \%)$ berusia $<55$ tahun. Dari 28 sampel melanoma maligna didapatkan sebanyak $16(57,1 \%)$ berusia $<55$ tahun dan 12 $(42,9 \%)$ berusia $\geq 55$ tahun.

\begin{tabular}{|c|c|c|}
\hline \multirow[t]{2}{*}{ Karakteristik } & \multicolumn{2}{|c|}{ Jenis Lesi } \\
\hline & Nevus melanositik (n-30) & Melanoma maligna $(\mathrm{n}=28)$ \\
\hline \multicolumn{3}{|l|}{ Usia } \\
\hline$<55$ tahun & $27(90,0)$ & $16(57,1)$ \\
\hline$\geq 55$ tahun & $3(10,0)$ & $12(42,9)$ \\
\hline
\end{tabular}

Berdasarkan jenis kelamin terdapat 23 sampel $(76,7 \%)$ berjenis kelamin perempuan dan $7(23,3 \%)$ laki-laki pada nevus melanositik sedangkan pada melanoma maligna sebanyak $15(53,6 \%)$ berjenis kelamin laki-laki dan 13 sampel $(46,4 \%)$ perempuan.

Tabel 1.3 Karakteristik klinikopatologi berdasarkan jenis kelamin

\begin{tabular}{ccc}
\hline Karakteristik & \multicolumn{2}{c}{ Jenis Lesi } \\
\cline { 2 - 3 } & Nevus melanositik (n-30) & Melanoma maligna (n=28) \\
\hline Jenis Kelamin & $7(23,3)$ & $15(53,6)$ \\
Laki-laki & $23(76,7)$ & $13(46,4)$ \\
Perempuan & & \\
\hline
\end{tabular}

Lokasi tumor terbanyak di kepala dan leher yaitu 25 sampel $(83,3 \%)$, tubuh 3 sampel (10\%), ekstremitas $2(6,7 \%)$ dan tidak ditemukan lesi di akral pada sampel nevus melanositik sedangkan pada melanoma maligna lokasi tumor terbanyak di kepala dan leher 10 sampel $(35,7 \%)$, dilokasi lain seperti tubuh, ekstremitas dan akral masing-masing sebanyak $6(21,4 \%)$ sampel.

\begin{tabular}{|c|c|c|}
\hline \multirow[t]{2}{*}{ Karakteristik } & \multicolumn{2}{|c|}{ Jenis Lesi } \\
\hline & Nevus melanositik (n-30) & Melanoma maligna $(\mathrm{n}=28)$ \\
\hline \multicolumn{3}{|l|}{ Lokasi Tumor } \\
\hline Kepala dan Leher & $25(83,3)$ & $10(35,7)$ \\
\hline Batang tubuh & $3(10,0)$ & $6(21,4)$ \\
\hline Ekstremitas & $2(6,7)$ & $6(21,4)$ \\
\hline Akral & $0(0,0)$ & $6(21,4)$ \\
\hline
\end{tabular}

Pada penelitian ini berdasarkan hasil perkalian antara proporsi sel tumor yang terpulas dan intensitas pulasan, didapatkan ekspresi p15 tinggi (>2) dan ekspresi p15 rendah (0-2) masing-masing sebanyak 29 sampel (50\%). Pada sampel nevus melanositik didapatkan ekspresi p15 tinggi sebanyak 29 sampel $(96,7 \%)$ dan rendah (0-2) hanya sebanyak 1 sampel (3,3\%). Dengan uji korelasi Spearman's rho didapatkan hasil terdapat hubungan negatif lemah dan tidak bermakna antara tingkat ekspresi p15 dan tipe histopatologi nevus melanositik ( $\mathrm{r}=-0,339$; $\mathrm{p}=0,067$ ) (Tabel 2).

Hubungan antara ekspresi p15 dan tipe histopatologi tidak bisa dianalisis dikarenakan semua sampel melanoma maligna memiliki ekspresi p15 rendah. Dengan uji korelasi Spearman's rho didapatkan hasil terdapat hubungan positif sangat kuat dan bermakna antara ekspresi p15 dan tipe lesi melanositik ( $\mathrm{r}$ $=0,966 ; \mathrm{p}=0,000)$ (Tabel 5.6). Semakin rendah ekspresi p15 maka semakin besar kemungkinan terjadi melanoma maligna (Tabel 3). 


\begin{tabular}{lllc}
\multicolumn{2}{l}{ Tabel 2. Hubungan ekspresi p15 dan tipe histopatologi nevus melanositik } & \multicolumn{2}{l}{} \\
\hline Ekspresi p15 & \multicolumn{1}{c}{ Tipe Histopatologi } & r & p value \\
\hline \multicolumn{1}{c}{ Rendah } & Compound nqevus & $-0,339$ & 0,067 \\
Tinggi & Dermal naewus & & \\
& Spitz naevus & & \\
& &
\end{tabular}

\begin{tabular}{lllc}
\multicolumn{2}{l}{ Tabel 3. Hubungan ekspresi p15 dan lesi melanositik } & & \\
\hline Ekspresi p15 & Tipe Lesi Melanositik & r & p value \\
\hline Rendah & Melanoma maligna & 0,966 & 0,000 \\
Tinggi & Naevus melanositik & & \\
\hline Spearman's rho, $\mathrm{p}=0,05$ & & &
\end{tabular}

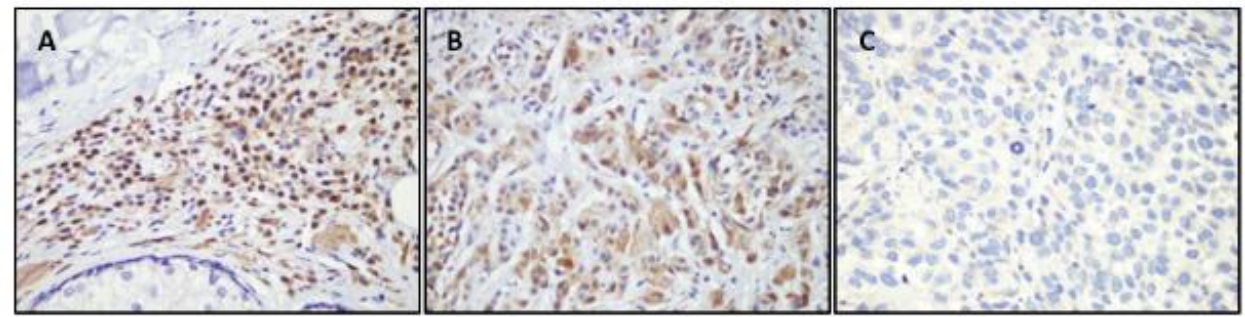

Gambar 1. Ekspresi p15. A. Intensitas ekspresi sedang sampai kuat. B. Insensitas lemah sampai sedang. C. Insensitas lemah sampai negatif.

\section{Pembahasan}

Pada penelitian ini didapatkan sebanyak $90 \%$ pasien nevus melanositik berusia $<55$ tahun dengan rerata usia 30,6 $\pm 17,11$ tahun. Hasil penelitian ini tidak jauh berbeda dengan penelitian Ghosh dkk pada tahun 2018 yang melaporkan sebanyak $89,2 \%$ pasien nevus melanositik berusia $<50$ tahun. ${ }^{1}$ Penelitian lain yang dilakukan Ramirez dkk pada tahun 2018 didapatkan rerata usia pasien nevus melanositik adalah 37,2 tahun dengan rentang 1 hingga 79 tahun. ${ }^{13}$ Menurut teori Unna yang dikenal sebagai teori Abtropfung, proliferasi melanosit pada nevus pigmentosus berkembang dari epidermis dan bermigrasi ke dermis. Teori ini membuktikan bahwa tahap perkembangan pada natural histori nevus pigmentosus dimulai dari proliferasi junctional, kemudian melewati taut dermoepidermal menjadi nevus compound yang terdiri dari komponen junctional dan dermis; lalu bermigrasi secara sempurna ke dalam dermis, kehilangan komponen junctional.
Studi dari Winkelmann dkk. yang melakukan evaluasi terhadap 1200 lesi berpigmen mendukung teori ini dengan hasil penelitiannya yang menunjukkan adanya dominasi nevus intradermal di antara individu yang lebih tua. Sedangkan pada pasien melanoma maligna didapatkan sebanyak $57,1 \%$ berusia $<55$ tahun dengan rerata usia $52,79 \pm 14,10$ tahun. Rerata usia pada penelitian ini sedikit lebih muda dibandingkan penelitian yang dilakukan Mulenga dkk pada tahun 2019 yang mendapatkan rerata usia pasien melanoma maligna sebesar 57,0 \pm 15,0 tahun.5 Penelitian lain yang dilakukan Malagoli dkk pada tahun 2019 melaporkan persentase pasien melanoma maligna dengan usia $<50$ tahun $(38,4 \%)$ lebih sedikit dibandingkan pasien dengan usia $>50$ tahun. ${ }^{14}$ Selain itu, penelitian yang dilakukan Enninga dkk pada tahun 2017 yang melibatkan 106.511 sampel didapatkan hasil pasien melanoma maligna dengan usia $<55$ tahun didapatkan sebanyak $47 \% .{ }^{15}$ Perbedaan ini kemungkinan disebabkan oleh jumlah sampel yang kecil 
pada penelitian ini dan adanya kesadaran yang cukup baik pada populasi remaja dan dewasa muda dengan menggunakan sunscreen sebagai pelindung dari paparan sinar UV sehingga didapatkan penurunan insiden melanoma maligna dalam populasi remaja dan dewasa muda. ${ }^{16}$ Secara keseluruhan, melanoma maligna paling sering didiagnosis pada pasien berusia 55-64 tahun dengan median usia 63 tahun. Rata-rata kejadian melanoma dijumpai lebih tinggi pada wanita sebelum usia 44 tahun. Distribusi bimodal yang relevan secara klinis ini menunjukkan rentang usia yang luas untuk pasien yang didiagnosis dengan melanoma maligna. ${ }^{17}$ Usia merupakan faktor prognostik yang penting pada melanoma maligna. Melanoma memiliki sifat biologis yang agresif, dengan bertambahnya usia akan semakin buruk prognosisnya. Batasan usia pada penelitian ini berdasarkan penelitianpenelitian sebelumnya. Pada penelitian ini rerata usia pasien melanoma maligna lebih tua dibandingkan pasien nevus melanositik $(52,79$ $\pm 14,10$ tahun dengan 30,6 \pm 17,11 tahun). Hasil tersebut sejalan dengan penelitian yang dilakukan Mikoshiba dkk pada tahun 2019 yang melaporkan rerata usia pasien melanoma maligna didapatkan lebih tua dibandingkan pasien nevus melanositik (65.3 dengan 38.0 tahun). ${ }^{18}$ Banyak individu dewasa memiliki nevus dengan jumlah yang sangat bervariasi dari satu individu ke individu lain, mulai dari hanya beberapa nevus hingga ratusan lesi per orang. Nevus jarang muncul saat lahir dan ketika muncul dikenal sebagai congenital naevus. Pembentukan nevi baru berkurang setelah usia 30 tahun) disertai adanya regresi klinis nevi yaitu suatu proses yang kurang dipahami di mana nevi berevolusi dan dapat menghilang seluruhnya. Frekuensi regresi nevus meningkat dengan bertambahnya usia. 3 Dibandingkan dengan lesi lain yang tampak secara klinis jinak, tetapi sifat nevi ini berpotensi sebagai prakanker. Nevus melanositik unik karena muncul relatif di awal kehidupan. Alasan mengapa nevi muncul terutama selama dua dekade pertama kehidupan dan berkurang dengan bertambahnya usia masih belum jelas. Adanya radiasi ultraviolet dan mutagen lingkungan lainnya kemungkinan besar berperan. ${ }^{3}$

Penelitian ini menunjukkan bahwa persentase pasien nevus melanositik dengan jenis kelamin perempuan $(76,7 \%)$ lebih banyak dibandingkan laki-laki. Hasil ini sejalan dengan penelitian Li dkk pada tahun 2019 yang melibatkan 1046 pasien nevus melanositik, didapatkan persentase pasien nevus melanositik dengan jenis kelamin perempuan $(70,5 \%)$ lebih banyak dibandingkan laki-laki. ${ }^{19}$ Penelitian lain yang dilakukan Ghosh et al dkk pada tahun 2018 juga mendapatkan persentase pasien nevus melanositik dengan jenis kelamin perempuan $(65 \%)$ lebih banyak dibandingkan laki-laki. ${ }^{1}$ Hal ini mungkin disebabkan oleh faktor hormonal. Menurut Hearing, hormon seks estrogen dan progesteron berinteraksi dengan melanosit, meskipun mekanismenya apakah proliferasi atau diferensiasi melanosit yang dipengaruhi belum diketahui. Sejumlah penelitian telah menemukan bahwa melanosit mengekspresikan reseptor untuk hormon ini, tetapi tidak diketahui apakah hormon ini memiliki efek utama pada pertumbuhan melanosit, aktivasi dari jalur melanogenik atau berikatan langsung dengan melanin.1 Sedangkan pada pasien melanoma maligna didapatkan persentase jenis kelamin laki-laki $(53,6 \%)$ lebih tinggi dari perempuan $(46,4 \%)$. Hal ini sesuai dengan penelitian Tsai dkk yang menyatakan melanoma pada laki-laki menunjukkan jumlah akumulasi mutasi gen akibat paparan sinar UV pertahun lebih tinggi dibandingkan pada perempuan disesuaikan dengan usia dan gejala klinis yang relevan. Laki-laki lebih rentan terjadinya mutasi yang mengakibatkan proliferasi dan pembelahan sel yang diinduksi oleh paparan sinar UV, berbeda dengan akumulasi mutasi pada perempuan walaupun dengan paparan sinar UV. ${ }^{20}$ Hasil ini sedikit berbeda dengan penelitian yang dilakukan Shaghaghian dkk pada tahun 2019 yang juga mendapatkan persentase pasien melanoma maligna dengan jenis kelamin lakilaki $(49,5 \%)$ lebih kecil dari perempuan 
$(51,5 \%){ }^{21}$ Penelitian lain yang dilakukan Malagoli dkk pada tahun 2019 didapatkan hasil yang sedikit berbeda dengan penelitian ini dimana persentase pasien melanoma maligna dengan jenis kelamin laki-laki $(46,1 \%)$ lebih sedikit dari perempuan $(53,9 \%) .{ }^{14}$ Perbedaan ini kemungkinan disebabkan faktor kosmetik pada beberapa perempuan yang ingin kulitnya terlihat berwarna gelap dengan cara berjemur dibawah sinar matahari (sunbathing) dan didalam ruangan (indoor tanning) sehingga paparan sinar UV ini dalam jangka waktu yang lama dan terus menerus dapat mengakibatkan kerusakan DNA dan memicu terjadinya melanoma maligna. ${ }^{16}$ Tsao dkk juga menyatakan resiko nevus berkembang menjadi melanoma lebih besar pada laki-laki yang berusia lebih dari 60 tahun. ${ }^{22}$

Penelitian ini menunjukkan lokasi tumor terbanyak pada pasien nevus melanositik adalah di kepala dan leher $(83,3 \%)$ dan tidak ditemukan lesi di akral. Hasil ini sejalan dengan penelitian Ghosh dkk pada tahun 2018 yang melaporkan bahwa lokasi terbanyak nevus melanositik adalah di wajah, kepala dan leher (92\%).1 Sedangkan penelitian yang dilakukan Li dkk pada tahun 2019 mendapatkan lokasi terbanyak nevus melanositik di kepala dan leher sebesar 51,4\%.19 Carli dkk (2002) menyatakan bahwa daerah yang biasanya terkena paparan sinar matahari secara kronis, misalnya wajah, memiliki kepadatan nevus pigmentosus yang lebih tinggi dibandingkan dengan regio yang sesekali terkena sinar matahari, misalnya badan dan daerah yang jarang terkena sinar matahari, misalnya telapak tangan, telapak kaki, lengan bagian dalam dan bokong. ${ }^{23}$

Kasus melanoma maligna didapatkan lokasi tumor terbanyak pada kepala dan leher (34,5\%). Hal ini sejalan dengan penelitian Ozgur dkk yang melaporkan lokasi terbanyak melanoma maligna pada regio kepala dan leher (80\%). Lokasi melanoma maligna pada kepala dan leher merupakan salah satu melanoma yang disebabkan paparan sinar UV secara kronis dan berulang atau dikenal sebagai
Chronic Sun Damage (CSD) melanoma. Penelitian ini juga menyebutkan area wajah, scalp, leher dan telinga luar merupakan area yang paling berpotensi untuk terpapar sinar matahari. $^{24}$

Radiasi sinar UV yang dihasilkan matahari memegang peranan penting pada perkembangan melanoma. Radiasi sinar UV diketahui dapat menginduksi kematian sel dan transformasi keganasan pada kulit. ${ }^{25}$ Secara teori, radiasi sinar UV secara langsung menstimulasi sinyal jalur MAPK yang merupakan jalur utama pada karsinogenesis yang diinduksi sinar UV. ERK, JNK dan p38 kinase diaktivasi sebagai respon terhadap sinar UV melalui fosforilasi threonine dan tyrosine. Aktivasi protein-protein ini menghasilkan translokasi inti sel dimana protein-protein ini pada gilirannya menjadi faktor-faktor transkripsi fosforilasi yang mengarah ke ekspresi gen target yang mengontrol jalur sel seperti proliferasi, differensiasi, perkembangan dan kematian sel. Aktivasi jalur MAPK yang diinduksi sinar UV ini berperan pada perkembangan melanoma. ${ }^{26}$ Berbeda dengan penelitian ini, penelitian yang dilakukan $\mathrm{Yu}$ dkk pada tahun 2016 melaporkan lokasi terbanyak pada akral. ${ }^{27}$ Begitu pula penelitian yang dilakukan Enninga dkk pada tahun 2017 didapatkan lokasi terbanyak di ekstremitas $(58,7 \%) .{ }^{15}$ Hal ini mungkin disebabkan oleh perbedaan faktor sosio-demografis letak negara Indonesia yang beriklim tropis dan kebiasaan penduduk yang beraktifitas di luar tanpa memakai pelindung dari paparan sinar UV. Adanya lokasi akral (palmoplantar atau subungual) dan ekstremitas merupakan sun-protected sites yang dapat menyebabkan non-CSD melanoma di mana tingkat paparan sinar UV yang berbeda mengarah pada serangkaian perubahan genetik yang berbeda pula. Berdasarkan biologi molecular acral melanoma sebagian besar disebabkan delesi atau amplifikasi KIT pada exon 9, 11, 13, 17 dan 18 sedikit berbeda dengan melanoma pada regio kepala dan leher yang sebagian besar disebabkan mutasi pada gen BRAF. ${ }^{28,17}$ 
Pada penelitian ini didapatkan tipe histopatologi yang paling banyak pada nevus melanositik adalah dermal naevus $(55,9 \%)$ sesuai dengan penelitian Damsky dkk yang menyatakan dermal naevus merupakan tipe histopatologi yang paling sering. ${ }^{3}$ Menurut konseps klasik nevus melanositik, junctional, compound, dan dermal naevus merupakan tahapan yang berbeda dari urutan patogenetik ("Abtropfung"). Namun pandangan ini telah lama diperdebatkan dan disimpulkan bahwa sel nevus dermal berkembang dari sel prekursor melanositik yang berada di bagian tertentu misalnya daerah tonjolan folikel rambut. Hubungan antara masing-masing tipe histopatologi dengan faktor apa yang menyebabkan bentukan salah satu tipe dibanding tipe lainnya masih belum jelas. Mutasi BRAF yang dominan ditemukan pada nevus melanositik tipe histopatologi dengan komponen dermal. $^{3}$

Tipe histopatologi yang paling banyak pada melanoma adalah nodular melanoma (42,9\%). Tidak seperti pada Wang dkk yang menyatakan superficial spreading melanoma merupakan tipe histopatologi yang paling banyak yaitu $70-80 \%$ dari seluruh tipe histopatologi melanoma sedangkan nodular melanoma hanya $15-30 \% .27$ Nodular melanoma merupakan salah satu tipe histopatologi melanoma yang berasal dari paparan sinar matahari. ${ }^{29}$ Pada penelitian ini nodular melanoma merupakan tipe histopatologi melanoma yang paling banyak dijumpai karena iklim di Indonesia yang merupakan daerah tropis dan juga karena pola hidup yang kurang menjaga kesehatan kulit seperti tidak memakai tabir surya pada kulit sehingga terjadi paparan sinar UV yang kronik dan terus menerus pada kulit.

Penelitian ini menggunakan uji korelasi Spearman's rho dengan memberikan hasil terdapat hubungan negatif lemah dan tidak bermakna antara tingkat ekspresi p15 dengan tipe histopatologi nevus melanositik ( $\mathrm{r}=$ 0,$339 ; p=0,067$ ). Tipe histopatologi nevus melanositik pada penelitian ini adalah compound naevus, dermal naevus dan spitz naevus. Tipe histopatologi compound naevus dan dermal naevus memberikan ekspresi p15 yang tinggi. Sejalan dengan penelitian Taylor dkk yang menyatakan ekspresi p15 rendah pada nevus melanositik tanpa memperhitungkan tipe histopatologi nevus melanositik dan belum ada penelitian lainnya yang menghubungkan tipe histopatologi nevus melanositik dengan ekspresi p15. ${ }^{30}$ Pada penelitian ini dijumpai satu tipe histopatologi spitz naevus memberikan ekspresi p15 yang rendah dengan analisa statistik didapatkan hubungan bermakna antara tipe histopatologi spitz naevus dengan ekspresi p15 rendah. Hasil ini berbeda dengan teori yang menyatakan spitz naevus memberikan gambaran atipia ringan dan resiko yang rendah untuk menjadi ganas. ${ }^{31}$ Perbedaan yang ditemukan ini kemungkinan dikarenakan ekspresi p15 rendah pada kelompok nevus hanya ditemukan pada satu sampel sehingga tidak bisa mewakili ketiga jenis tipe histopatologi nevus melanositik. Kemungkinan lain juga dapat dikarenakan proses fiksasi jaringan yang kurang adekuat sehingga mengurangi ekspresi p15 dan juga bahwa sampel ini merupakan suatu spitz melanoma. Gen CDKN2B yang mengkode p15 mengalami upregulasi yang tinggi pada nevus melanositik sehingga menjaga nevus melanositik tetap pada fase growth arrest. Peran p15 ini akan hilang pada melanoma maligna. ${ }^{32,33}$

Terdapat empat tipe histopatologi melanoma maligna pada penelitian ini yaitu mucosal melanoma, nodular melanoma, akral melanoma dan conjunctival melanoma. Semua spesimen melanoma maligna pada penelitian ini memiliki ekspresi p15 rendah. Analisa statistik tidak dapat dilakukan pada kelompok tipe histopatologi ini karena semua spesimen memiliki ekspresi p15 rendah (100\%) yang didapat dari hasil perkalian antara proporsi luas daerah dan intensitas pulasan. Hal ini sejalan dengan penelitian yang dilakukan oleh Taylor dkk menyatakan bahwa pada melanoma maligna ekspresi p15 lebih rendah daripada ekspresi p15 pada nevus melanositik tanpa memperhatikan tipe histopatologi melanoma 
maligna. p15 merupakan efektor utama OIS pada nevomelanocytes yang akan berkurang pada melanoma maligna. Pada melanosit kehilangan p15 diketahui secara langsung meningkatkan transisi dari nevus melanositik ke melanoma maligna. ${ }^{31}$

Pada penelitian ini didapatkan hubungan negatif lemah dan tidak bermakna antara tingkat ekspresi p15 dengan tipe histopatologi pada nevus melanositik maupun melanoma maligna. Namun didapatkan hasil adanya hubungan positif bermakna antara ekspresi p15 dan lesi melanositik, semakin rendah ekspresi p15 semakin besar kemungkinan terjadi melanoma maligna. Hal ini sesuai dengan penelitian yang dilakukan oleh Taylor dkk menyatakan bahwa pada melanoma maligna ekspresi p15 lebih rendah daripada ekspresi p15 pada nevus melanositik. ${ }^{31}$ Sesuai dengan penelitian Vermeulen $\mathrm{K}$ yang menyatakan adanya delesi pada gen p15 dan kegagalan replikasi pada siklus sel terjadi pada stadium awal melanoma sedangkan mutasi p15 mungkin terjadi pada tahap selanjutnya dari tumorigenesis melanoma. ${ }^{34}$ Pada nevus melanositik tidak dijumpai adanya delesi dan mutasi pada gen p15. Pertumbuhan nevus melanositik dapat terhenti walaupun hanya sebagian kecil akan berkembang.3,32 p15 berinteraksi dengan CDK4/6 dan diregulasi oleh TGF- $\beta$. Ketika TGF- $\beta$ diinduksi maka p15 akan berikatan dan menghambat CDK sehingga sel normal tidak akan tumbuh terus menerus. Interaksi antara p15 dengan CDK akan menghambat pembelahan sel sehingga memungkinkan untuk terjadinya perbaikan DNA dan/atau apoptosis pada sel-sel yang rusak atau terganggu. Terjadi mutasi pada p15 kromosom 9p21 pada melanoma yang menyebabkan efek inhibisi dari TGF- $\beta$ hilang, sehingga sel kanker akan terus tumbuh. ${ }^{34,35}$

\section{Kesimpulan}

Ekspresi p15 dijumpai tinggi pada nevus melanositik dan rendah pada melanoma maligna. Dengan adanya marker p15 ini dapat menjadi faktor prediktor pada melanoma maligna sehingga dapat membantu patolog dalam menegakkan diagnosa yang akurat terutama pada kasus-kasus yang sulit membedakan antara nevus melanositik dan melanoma maligna serta dapat pula membantu klinisi dalam menegakkan diagnosa dan menentukan terapi.

\section{Daftar Pustaka}

1. Mulenga M, Montgomery ND, Chagomerana M, Mzumala T, Tomoka T, Kampani C, et al. Epidemiological and histopathological profile of malignant melanoma in Malawi. BMC Clin Pathol. 2019;19(1):1-6.

2. Syaputri NA, Musa Z, Septadina IS. Karakteristik Histopatologi Melanoma Maligna di Bagian Patologi Anatomi RSUP Dr. Moh. Hoesin Palembang Tahun 2009-2013. Biomed J Indones. 2018;4(1):26-31.

3. Bogenrieder T, Herlyn M. The molecular pathology of cutaneous melanoma. Cancer Biomarkers. 2011;9(1-6):267-86.

4. Bsirini C, Smoller BR. Histologic mimics of malignant melanoma. Singapore Med J. 2018;59(11):602.

5. Hale CS. Nevoid melanoma [Internet]. [cited 2020 May 31]. Available from: http://www.pathologyoutlines.com/topic/ skintumormelanocyticnevoidmelanoma.h tml

6. Theodosiou G, Johansson I, Hamnerius N, Svensson A. Naevoid malignant melanoma: a diagnosis of a naevus that you later regret. Acta Derm Venereol. 2017;97(6-7):745-6.

7. Costa S, Byrne M, Pissaloux D, Haddad $\mathrm{V}$, Paindavoine S, Thomas $\mathrm{L}$, et al. Melanomas associated with blue nevi or 
mimicking cellular blue nevi. Am J Surg Pathol. 2016;40(3):368-77.

8. Ghosh A, Ghartimagar D, Thapa S, Sathian B, Shrestha B, Talwar OP. Benign melanocytic lesions with emphasis on melanocytic nevi-A histomorphological analysis. J Pathol Nepal. 2018;8(2):13848.

9. Koh SS, Cassarino DS. Immunohistochemical expression of p16 in melanocytic lesions: an updated review and meta-analysis. Arch Pathol Lab Med. 2018;142(7):815-28.

10. Feuerer L, Lamm S, Henz I, KappelmannFenzl M, Haferkamp S, Meierjohann S, et al. Role of melanoma inhibitory activity in melanocyte senescence. Pigment Cell Melanoma Res. 2019;32(6):777-91.

11. El-Deiry WS. p21 (WAF1) mediates cellcycle inhibition, relevant to cancer suppression and therapy. Cancer Res. 2016;76(18):5189-91.

12. Zhang Y, Guo L, Xing P, Chen Y, Li F, $\mathrm{Zhu} \mathrm{W}$, et al. Increased expression of oncogene-induced senescence markers during cervical squamous cell cancer development. Int $\mathbf{J}$ Clin Exp Pathol. 2014;7(12):8911.

13. González-Ramírez RA, Guerra-Segovia C, Garza-Rodríguez V, Garza-Báez P, Gómez-Flores M, Ocampo-Candiani J. Dermoscopic features of acral melanocytic nevi in a case series from Mexico. An Bras Dermatol. 2018;93:66570.

14. Malagoli C, Malavolti M, Farnetani F, Longo C, Filippini T, Pellacani G, et al. Food and beverage consumption and melanoma risk: A population-based casecontrol study in northern Italy. Nutrients. 2019;11(9):2206.

15. Enninga EAL, Moser JC, Weaver AL, Markovic SN, Brewer JD, Leontovich AA, et al. Survival of cutaneous melanoma based on sex, age, and stage in the United States, 1992-2011. Cancer Med. 2017;6(10):2203-12.

16. Guy Jr GP, Thomas CC, Thompson T,
Watson M, Massetti GM, Richardson LC. Vital signs: melanoma incidence and mortality trends and projections-United States, 1982-2030. MMWR Morb Mortal Wkly Rep. 2015;64(21):591.

17. Merkel EA, Gerami P. Malignant melanoma of sun-protected sites: a review of clinical, histological, and molecular features. Lab Investig. 2017;97(6):630-5.

18. Mikoshiba $Y$, Minagawa A, Koga H, Yokokawa Y, Uhara H, Okuyama R. Clinical and histopathologic characteristics of melanocytic lesions on the volar skin without typical dermoscopic patterns. JAMA dermatology. 2019;155(5):578-84.

19. Li Q-X, Swanson DL, Tu P, Yang S-X, Li $\mathrm{H}$. Clinical and dermoscopic features of surgically treated melanocytic nevi: a retrospective study of 1046 cases. Chin Med J (Engl). 2019;132(17):2027.

20. Tsai K-C, Hung S-J, Wang J-H, Huang S$\mathrm{J}$, Wang C-H, Lee J-T, et al. Cutaneous malignant melanoma in eastern Taiwan: Clinicopathologic analysis of 56 cases. Dermatologica Sin. 2019;37(4):187.

21. Shaghaghian E, Namazi MR, Shaghaghian A. Epidemiological Study of Cutaneous Malignant Melanoma in Shiraz, Southwest of Iran between 2011 and 2016.

22. Vezzoni R, Conforti C, Vichi S, Giuffrida R, Retrosi C, Magaton-Rizzi G, et al. Is there more than one road to nevusassociated melanoma? Dermatol Pract Concept. 2020;10(2).

23. Tsaniyah RAD, Aspitriani A, Fatmawati F. Prevalensi dan Gambaran Histopatologi Nevus Pigmentosus di Bagian Patologi Anatomi Rumah Sakit Dr. Mohammad Hoesin Palembang Periode 1 Januari 2009-31 Desember 2013. Maj Kedokt Sriwij. 2015;47(2):110-4.

24. Özgür E, Karakullukçu B, Eskiizmir G. Current Treatment Strategies in Cutaneous Malignant Melanoma of the Head and Neck. ENT Updat. 2019;9(1):25-33. 
25. Seebode C, Lehmann J, Emmert S. Photocarcinogenesis and skin cancer prevention strategies. Anticancer Res. 2016;36(3):1371-8.

26. Davis LE, Shalin SC, Tackett AJ. Current state of melanoma diagnosis and treatment. Cancer Biol Ther. 2019;20(11):1366-79.

27. Yu J, Luo X, Huang H, Zhai Z, Shen Z, Lin H. Clinical characteristics of malignant melanoma in Southwest China: a single-center series of 82 consecutive cases and a meta-analysis of 958 reported cases. PLoS One. 2016;11(11):e0165591.

28. Tod BM, Schneider JW, Bowcock AM, Visser WI, Kotze MJ. The tumor genetics of acral melanoma: What should a dermatologist know? JAAD Int. 2020;1(2):135-47.

29. Wang Y, Zhao Y, Ma S. Racial differences in six major subtypes of melanoma: descriptive epidemiology. BMC Cancer. 2016;16(1):1-19.

30. Elder DE, Bastian BC, Cree IA, Massi D, Scolyer RA. The 2018 World Health Organization classification of cutaneous, mucosal, and uveal melanoma: detailed analysis of 9 distinct subtypes defined by their evolutionary pathway. Arch Pathol Lab Med. 2020;144(4):500-22.

31. Taylor LA, O'Day C, Dentchev T, Hood K, Chu EY, Ridky TW, et al. p15 expression differentiates nevus from melanoma. Am J Pathol. 2016;186(12):3094-9.

32. Verardino GC, Rochael MC. Spitz nevi in the classic histopathological patternlamb in wolfs clothing. An Bras Dermatol. 2015;90:91-5.

33. McNeal AS, Liu K, Nakhate V, Natale CA, Duperret EK, Capell BC, et al. CDKN2B loss promotes progression from benign melanocytic nevus to melanoma. Cancer Discov. 2015;5(10):1072-85.
34. Vermeulen K, Van Bockstaele DR, Berneman ZN. The cell cycle: a review of regulation, deregulation and therapeutic targets in cancer. Cell Prolif. 2003;36(3):131-49.

35. Leonardi GC, Falzone L, Salemi R, Zanghì A, Spandidos DA, Mccubrey JA, et al. Cutaneous melanoma: From pathogenesis to therapy. Int $\mathrm{J}$ Oncol. 2018;52(4):1071-80. 